\title{
THE
}
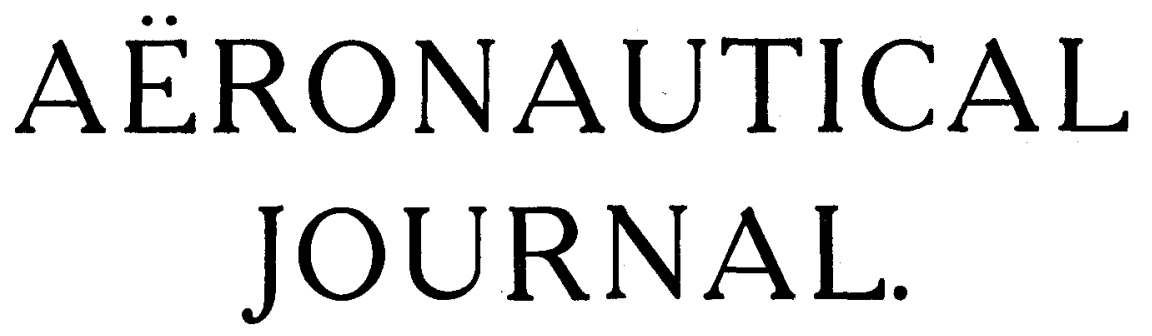

A Quarterly Illustrated Magazine devoted to all subjects connected with the Navigation of the Air.

\section{EDITED FOR THE}

Council of the Aëronautical Society of Great Britain BY

BERTRAM G. COOPER, A.F.AË.S.

\section{VOL. XVIII.}

\section{4.}

Printed by the Lewes Press, Ltd., High Street, Lewes, and published by the Aëronautical Society of Greàt Britain, I I, Adam Street, Adelphi, London, W.C. 